\title{
OUTCOME BASED LEARNING: THE EFFECT OF EXPERIENTIAL LEARNING ACTIVITY ON DEEP CONCEPTUAL UNDERSTANDING
}

\author{
Prashant Thote ${ }^{1} \mathbb{U}$ and Gowri. $\mathrm{S}^{1}$ \\ ${ }^{1}$ Gyanodaya Vidya Mandir, India
}

Received 18 May 2021

Accepted 1 June 2021

Published 30 June 2021

Corresponding Author

Prashant Thote, prashant.thote@r ediffmail.com

DOI 10.29121/

granthaalayah.v9.i6.2021.3953

Funding: This research received no specific grant from any funding agency in the public, commercial, or not-for-profit sectors.

Copyright: (C) 2021 The Author(s). This is an open access article distributed under the terms of the Creative Commons Attribution License, which permits unrestricted use, distribution, and reproduction in any medium, provided the original author and source are credited.

OPEN ACCESS

\section{ABSTRACT}

The aim of the present study is to investigate the effect of experiential learning activity in deep conceptual understanding of science in comparison with conventional teaching model. In the present experiment quasi experimental pre-test and post-test research design is implemented. Totally 80 students participate in the study: 40 girls and 40 boys. The sample is categorized into two: study and the control group. Each group consists of 40 students: 20 boys and 20 girls. The study group is taught "Gases Law" by using experiential learning activities and the control is taught by using the conventional method. Data is collected by using a questionnaire and it consists of 20 multiple choice questions. The collected data is analyzed by using descriptive statistics. The examination of the pre-test data illustrates that there is no noteworthy difference in the pre-test mean score between the study group and the control group. Independent 't-test' is applied to compare the student's achievement in post-test. The mean score of the study group, who are exposed to the experiential learning activities, in Science Achievement post-test is 17.35. It is higher than that of $(t=6.65 ; p>0.01)$ the learners in the control group. The mean of the control group is 14.45 . Therefore, it is concluded that the experiential learning activities as a teaching model enhances the deep conceptual understanding of science.

Keywords: Gases Law, Charles Law, Boyles Law, Avogadro's Law, States Of Matter

\section{INTRODUCTION}

"Real education consists of drawing best out of yourself. What better book can there be than the book of humanity?" - Mahatma Gandhi.

Experiential learning is a method of learning through experiences. It is learning through reflection by solving day to day life problems. Teachers know that students learn more quickly and they retain more when the subject matter relates them personally and these hands- on activity make learning exceptionally personal. 
Learning is best regarded as a process not measured in terms of outcome. To enhance the learning, principle focus should be on making the students to actively participate in the process. It includes constructive feedback during the process. Education is nothing but edifice of experiences. In the present century, learning is facilitated by continuous re-learning process in terms of beliefs and ideas that exists and through examining, testing and integrating with new and more innovative ideas.

People are like tea bag; they learn new things when they get into the hot water. Similarly effective learning takes place when the learners are put under difficult situation. They learn more during the process of problem solving or during the resolution of conflict. The key driving forces of learning are disagreement/differences and reflection of two opposite models. Learning is a holistic process and it encompasses integration of whole personality - feeling, thinking, pursuing and acting and result is the outcome of the synergic transition between the learner and climate. Learning also involves generating new knowledge and not just retaining knowledge.

Experiential learning activities are the teaching model which provides ample opportunities for the learners to acquire skills, knowledge and attain the intended learning outcome through firsthand experiences. These gained experiences help students to relate what they learn in their daily life situation.

The experiential learning activity fosters capacity development, creative thinking, critical thinking, observational skill, problem solving approach and positive mental attitude. Experiential learning activity involves participation of learners at sensory, emotional and intellectual level. Classroom instructions are not only for framing the knowledge but also to apply this gained knowledge into practice. It fosters student's ability to transform learning into the form of creative thinking.

Well planned experiential learning activity enhances academic motivation, promotes inter-disciplinary learning, magnifies cultural awareness and helps in professional, intellectual and personal enlargement. Experiential learning generates the chances to learn from the natural consequences, mistakes, problems and successes.

The effective learning activity promotes active participation of students to learn at their own. Students learn when they are given choice to solve the problems with proper support and encouragement to discover the relevant knowledge and possible alternatives to resolve the problem. It is an art and science designed for group and individual activity to germinate problem solving strategies, to articulate ideas and to logically argue with their counterparts.

\section{Experiential learning activity Specific Learning outcome}

The designed experiential learning activity uses balloon and glass bottle/flask to demonstrate the association between the volume and temperature of the gases. Learners are asked to fix the balloon on the opening end of the glass bottle/flask and are asked to observe the reaction of balloon at different temperature. At the finish of this experiential learning activity students will learn about the relation between energy and temperature. 


\section{Content/Topic:}

- Scientific based enquiry

- Skills for measuring temperature

- Skills for measuring the mass of substance

- States of the matter (classification)

- Properties of gases such as law, matter, energy

\section{Material required}

1. Glass bottle/flask

2. Balloon

3. Water

4. Hot electrical plate

\section{Experiment}

The learners are asked to perform the experiential learning activity and challenge them to identify the control and uncontrolled variables. Learners are asked to setup control for experiential learning activity for example: Does the change in temperature of gas affects the volume of gas?

\section{Procedure}

\section{Section A}

- Fill $60 \%$ of the glass bottle/flask with cold water.

- Cover the mouth of the glass bottle/flask with balloon.

- Place the glass bottle/flask on the hot electric plate.

- Boil the water - Once the water starts boiling due to the expansion of the air, the balloon gets inflated. Vaporization of water also contributes for the inflation.

- Remove the bottle/flask from the hot plate and allow it to cool.

\section{Section B}

- Fill $60 \%$ of the glass bottle/flask with hot water.

- Cover the mouth of the glass bottle/flask with balloon.

- Place the glass bottle/flask on the hot electric plate.

- Boil the water.

- Remove the glass bottle/flask from the hot plate and allow it to cool down for ten seconds.

- Once the water cools down the balloon gets sucked into the glass bottle/flask. 
Matter is defined as a substance that has mass and occupies volume. Everything that surrounds us is matter. Matter is characterized and classified according to its properties. Mass and volumes are the two basic properties of matter. Mass is the measurement of quantity of matter in the substance. An object's mass is measured with the help of the balance. To determine the mass, the object is compared with another object of known mass. The unit of measurement that scientists use to measure the mass is Kilogram/gram. Volume is measured to find the amount of place occupied by the substance and it is measured in number of ways. Volume is measured in litters and in cubic centimeter.

Matter exists principally in solid, liquid and gas form on earth. Solids have fixed volume and shape. Examples of solids are trees, glasses and chairs. Liquids have definite volume but no fixed shape. Examples of liquids are oil, water and milk. Gases have neither fixed shape nor volume. Volume and shape of the gas is determined by vessels that it contains. Examples of gases include argon, oxygen and nitrogen which along with other gases makes air around us.

Likewise different forms of energies are identified using different properties. Energy is the measurement of ability to generate energy. Energy is found in many forms and it changes from one form to other. Some form of energy includes kinetic energy, thermal energy, chemical energy and light energy. Temperature is the measurement of average kinetic energy (energy of the motion of the particle) of substance. It measures how fast the particles are moving around. The temperature of the substance is measured using thermometer.

Gases are defined by well set of laws called gases law. Gases law describes the relationship between volume, temperature and pressure,

\section{Charles law}

It explains the relationship between temperature and volume. It states that volume and temperature of the gas is directly proportional. As the temperature of gas increases, volume of the gas also increases. It illustrates that they change at the constant rate for example: $\frac{1}{2}$ is proportional to $2 / 4$ and $3 / 6$.

In the present experiential learning activity balloon is placed over the opening end of the glass bottle/flask. Air inside the glass bottle/flask is heated and expands. This causes the balloon to bloat. When hot air cools down the volume of the gas tries to pull more air from outside, as a result this balloon is pulled inside the glass bottle/flask.

\section{Formula and equation}

The volume and the temperature of the gases are directly proportional and hence the volume to temperature is constant.

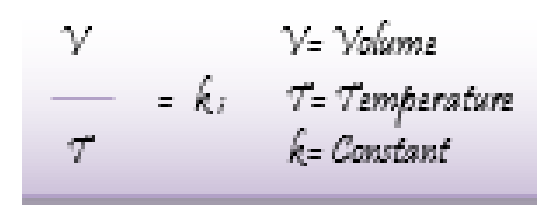


It is possible to solve the problem based on change in volume and temperature by using the equation,

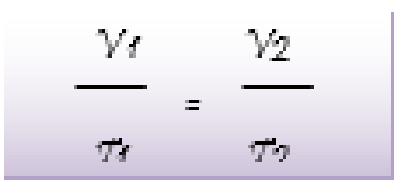

\section{Boyles Law}

At a constant temperature the product of pressure volume of an ideal gas is constant$$
D V=k
$$$$
V=\text { Volume; } 2=\text { Drasura; } k=\text { Constant }
$$

It is also used to solve the problems for change in pressure and volume by using equation

$$
D_{1} V_{1}=D_{2} V_{2}
$$

\section{Gay Lussa's Law}

Pressure exerted on a container is directly proportional to temperature of the gas.

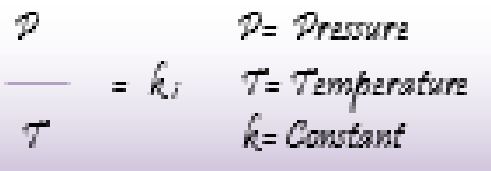

It is also used to calculate the change in pressure and temperature by using following properties

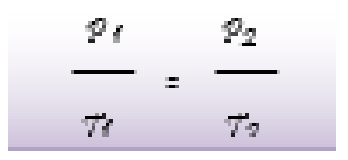

\section{Avogadro's law}

Equal volume of gas at the same temperature and pressure contains the same number of molecules (n) regardless of their chemical nature and physical properties. This Avogadro's number is $6.023 \times 10^{23}$

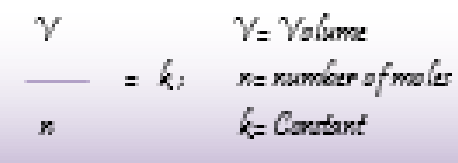




\section{Ideal gas law}

It is the combination of above all laws that relates temperature, pressure and volume.

$$
Q Y=x V^{2}
$$

This equation is called as ideal because it is based on hypothetical ideal gas. This law serves as a useful approximation for most of the gases under various conditions.
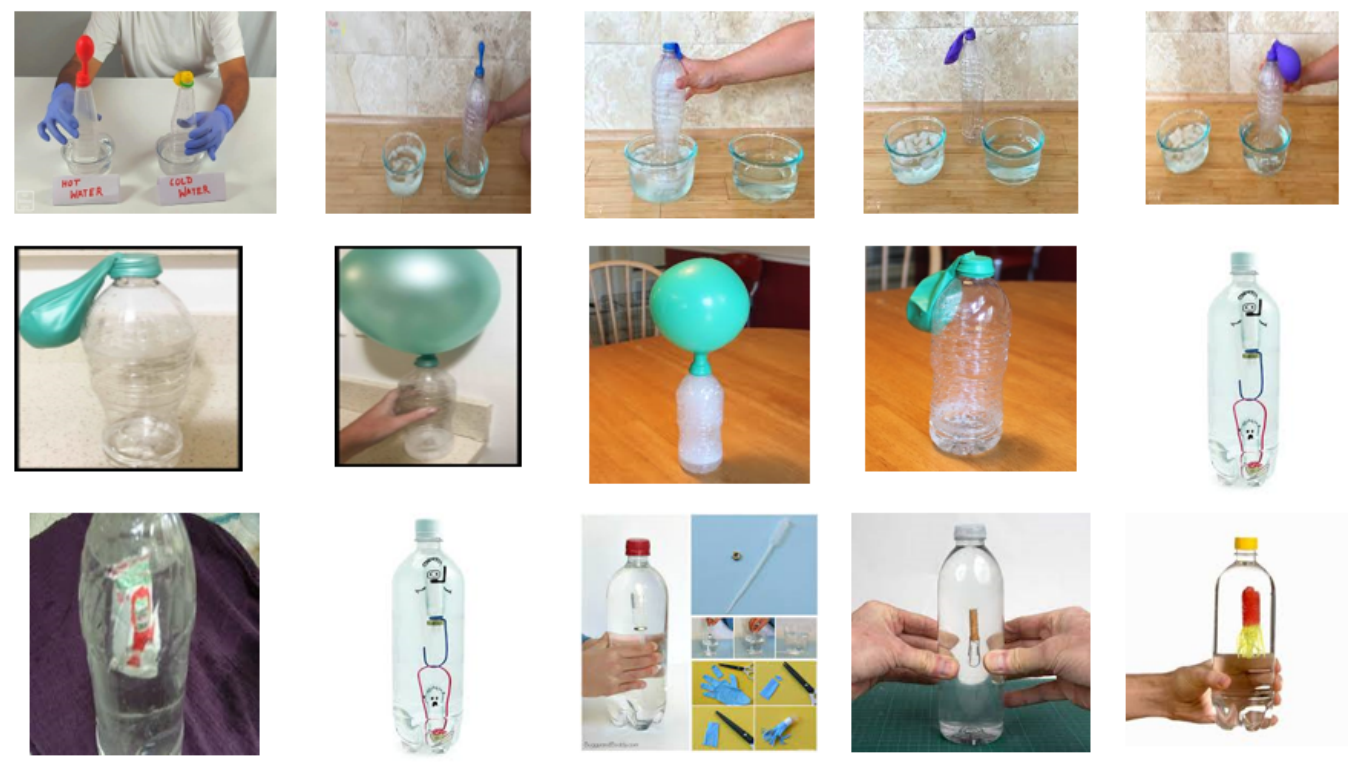

Figure 1 Activities

\section{Objective of the study}

The present study is sought to investigate the effect of experiential learning activities on academic achievement of students.

\section{METHODS}

\section{Research Design}

The experimental research design by applying formative assessment before the treatment and after the treatment is applied to the study.

\section{Sample}

Totally 80 students participate in the study. Sample is drawn from the two sections. Each section has 40 students. One session is randomly assigned as study group and another session is randomly assigned as control group. To maintain the ecosystem of the school with minimal disruption on, intact class is used. Author taught students of both the group to evade any teacher effect. Table 1 summarizes the descriptive statistics of the sample. 


\begin{tabular}{ccccccc}
\hline Table 1 Descriptive statistics of the sample \\
\hline Variables & \multicolumn{7}{c}{ Gender } & Total \\
\hline & Boys & Girls & & \\
\hline N & $\%$ & N & $\%$ & N & $\%$ \\
\hline Control Group & 20 & 25 & 20 & 25 & 40 & 50 \\
Total & 40 & 50 & 40 & 50 & 80 & 100 \\
\hline
\end{tabular}

\section{Tool}

Data is collected by using questionnaire called formative assessment. It consists of 20 multiple questions on conceptual understanding of Charles law. Each multiplechoice questions have four distracters and one correct response. To enhance the content validity test items are examined by two experts. The reliability of tool is estimated as 0.79 . The same tool is used for both before and after the treatment. The unit "states of Matter" of class XI the content gases law is taught by using experiential learning activities to the students of study group and conventional method is used for teaching the students of control group. Both groups are taught by the researcher.

\section{RESULT AND DISCUSSIONS}

\section{Data Analysis}

The data collected by using the tool is washed and analyzed. The collected by using the formative assessment before the treatment is analyzed first. It is analyzed by using independent sample $t$ test to establish the group equivalence of initial students' achievement. Both study and control are statistically noteworthy on pre-test are equivalent. Post-test data is analyzed by using ANCOVA with pre-test data serving as co-variate.

\begin{tabular}{|cccccccccc}
\hline Table 2 & pre-test (mean, SD and t-test) \\
\hline Variable & \multicolumn{1}{c}{ Study Group } & \multicolumn{2}{c}{ Control Group } & t & P \\
& N & Mean & SD & N & Mean & SD & & \\
Pre-test & 40 & 14.20 & 4.44 & 40 & 12.90 & 2.90 & 2.96 & .108 \\
\hline
\end{tabular}

Table 3 post-test (mean, SDand t-test)

\begin{tabular}{lccccccccc}
\hline Variable & \multicolumn{2}{c}{ Study Group } & \multicolumn{3}{c}{ Control Group } & \multicolumn{2}{c}{ t } & \\
& & Mean & SD & & Mean & SD & & \\
Post-test & 40 & 17.35 & 3.65 & 40 & 14.45 & 2.69 & 6.65 & .000 \\
\hline
\end{tabular}

Table 2 data depicts that the mean score in formative assessment before the treatment of study group is 14.20 and for control group it is 12.90 . The mean difference 


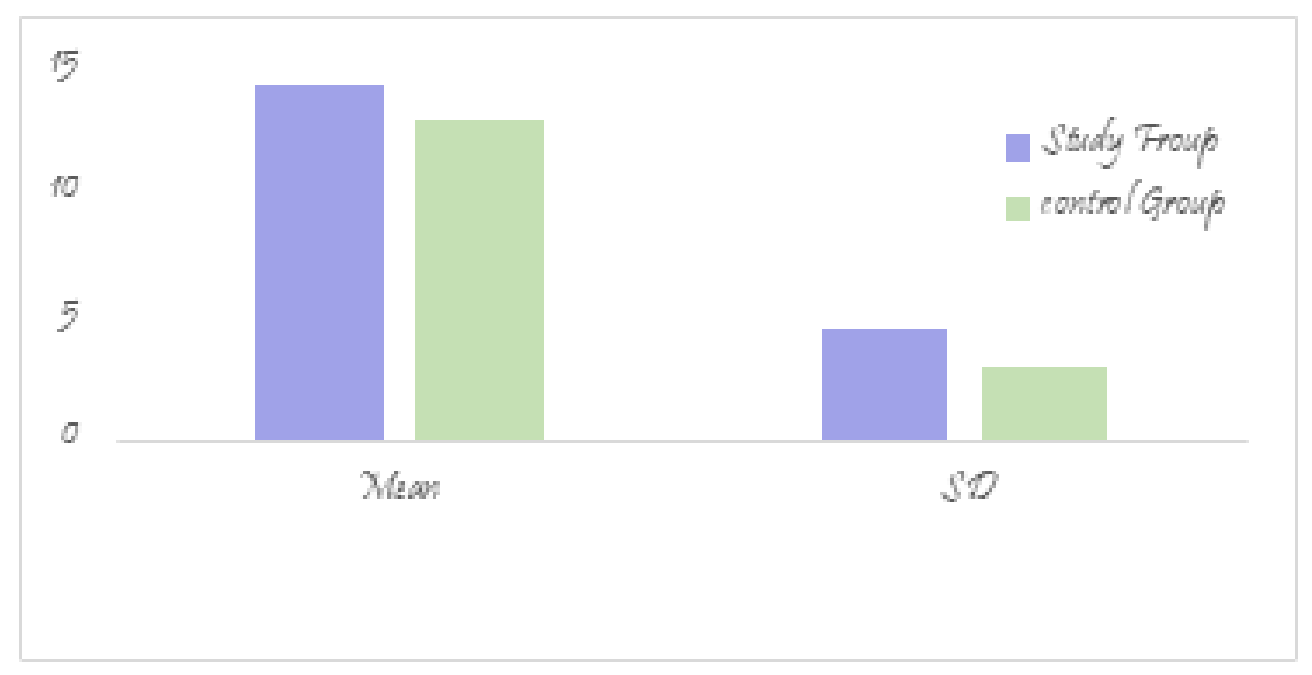

Figure 2 Pre-testscore of Mean and SD

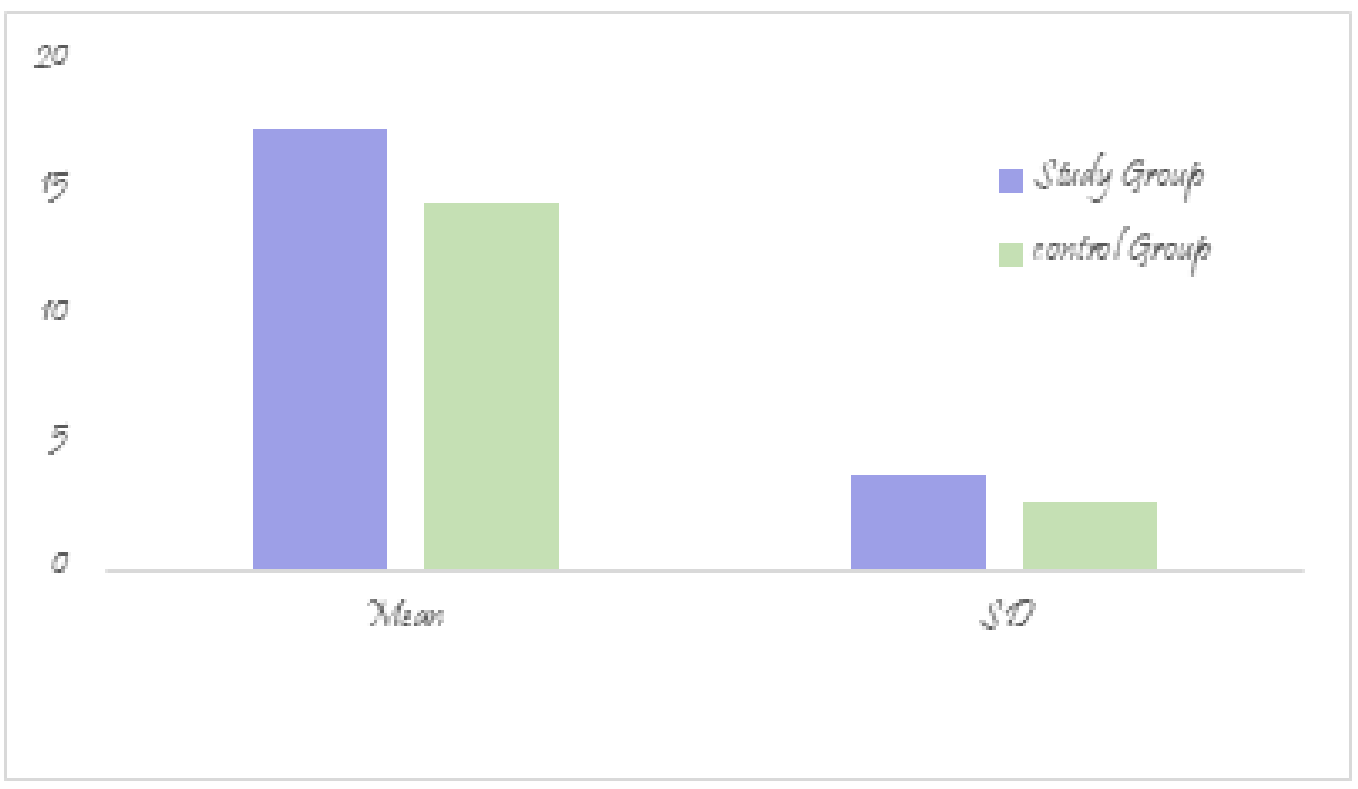

Figure 3 Post-testscore of Mean and SD

is 1.30 and it is not statistically noteworthy $(t=2.96 ; p=.108>0.05)$. The result of the study depicts that the mean score of the study group and control group in the formative assessment before the treatment is not significant. Hence post formative assessment after the treatment data is analyzed by using independent sample $t$ test given the equivalence to both the group.

Result of Table 3 represents the analysis of formative date after the treatment. The mean score of the study group is 17.35 and for control group it is 14.45 . The mean score difference between the study group and the control group is 2.9 in the formative 
assessment conducted after the treatment $(\mathrm{p}=0.000<0.001)$. This mean difference is noteworthy and real. Hence null hypothesis that there is no noteworthy difference in the learning of Charles law among the learners of Grade XI who are exposed to experiential activities and conventional teaching methodology is rejected.

The objective of the present study is to determine the effectiveness of experiential learning activities in comparison with conventional teaching method in enhancing the student's achievement in chemistry among the learners of Grade XI. The key findings of the study reveals that the experiential learning activity has positive effect on student achievement in learning gases law especially Charles law.

\section{CONCLUSION}

The present study illustrates that the experiential learning activities are important and they a play vital role in selecting the method of presenting the lessons for increasing the performance in chemistry. It is clearly observed that experiential learning activities:

- Assist teachers' lesson delivery and make it easier. It allows the leaners to interact better with their lessons. It makes learning exciting and fun and encourages active participation and brings learning homewards and improves and enhances the learners' performance.

- Is an effective tool to respond effectively and to handle diverse classroom situation and enhance active participation of learners in teaching- learning process. It is the basis of choosing and establishing the type of learning activities into experiential learning cycle.

- Experiential learning activity is the best teaching method and makes learning more interesting and more meaningful. Hence learning must be the outcome of experiences.

- Experiential learning activities make teaching-learning more effective when subject content is related to personal interest of the learners.

- It initiates self -initiated learning among the learners by reflecting on their own performances and students pay more attention on their own thinking process.

\section{REFERENCES}

Thote, P. (2019). Experiential Learning: Inclusive Art Education For Joyful Learning., 8, 9-9. Thote, P., \& Learning, E. (2019). Model For Teaching Science At Grade Nine. Research Magma, $3(06)$.

Thote, P., \& S, G. (2020a). AN ANALYSIS OF IMPACT OF EVIDENCE BASED LEARNING ON ACADEMIC ACHIEVEMENT OF STUDENTS. International Journal of Research -GRANTHAALAYAH, 8(8), 207-216. Retrieved from https://dx.doi.org/10.29121/ granthaalayah.v8.i8.2020.869 10.29121/granthaalayah.v8.i8.2020.869

Thote, P., \& S, G. (2020b). EVIDENCE BASED LEARNING: AN ANALYSIS OF IMPACT ON RETENTION OF KNOWLEDGE. International Journal of Research -GRANTHAALAYAH, 
8(10), 224-235. Retrieved from https://dx.doi.org/10.29121/granthaalayah.v8.i10 .2020 .1883 10.29121/granthaalayah.v8.i10.2020.1883

Thote, P., \& S, G. (2020c). EXPERIENTIAL LEARNING: AN ANALYSIS OF IMPACT ON ACADEMIC ACHIEVEMENT AMONG STUDENTS OF GRADE 12. International Journal of Research -GRANTHAALAYAH, 8(9), 188-199. Retrieved from https://dx.doi.org/10 .29121/granthaalayah.v8.i9.2020.1337 10.29121/granthaalayah.v8.i9.2020.1337

Thote, P., \& S, G. (2020d). OUTCOME BASED LEARNING: AN ANALYSIS OF IMPACT ON ACADEMIC ACHIEVEMENT AMONG SCHOOL STUDENTS. International Journal of Research -GRANTHAALAYAH, 8(11), 89-94. Retrieved from https://dx.doi.org/10 .29121/granthaalayah.v8.i11.2020.2222 10.29121/granthaalayah.v8.i11.2020.2222

Thote, P., \& S, G. (2021a). EVIDENCE BASED LEARNING: AN ANALYSIS OF IMPACT OF EXPERIENTIAL LEARNING ON ATTAINMENT OF INTENDED SPECIFIC LEARNING OUTCOME. International Journal of Research -GRANTHAALAYAH, 9(1), 6674. Retrieved from https://dx.doi.org/10.29121/granthaalayah.v9.i1.2021.2971 10 .29121/granthaalayah.v9.i1.2021.2971

Thote, P., \& S, G. (2021b). EVIDENCE BASED LEARNING: AN ANALYSIS OF IMPACT OF REMEDIAL TEACHING ON CONCEPTUAL UNDERSTANDING. International Journal of Research -GRANTHAALAYAH, 8(12), 211-224. Retrieved from https://dx.doi.org/10 .29121/granthaalayah.v8.i12.2020.2606 10.29121/granthaalayah.v8.i12.2020.2606

Thote, P., \& S, G. (2021c). EVIDENCE BASED LEARNING: AN ANALYSIS OF IMPACT OF TEACHER'S DESIGN MODEL ON CONCEPTUAL UNDERSTANDING. International Journal of Research -GRANTHAALAYAH, 9(3), 71-77. Retrieved from https://dx.doi.org/ 10.29121/granthaalayah.v9.i3.2021.3702 10.29121/granthaalayah.v9.i3.2021.3702

Thote, P., \& S, G. (2021d). EVIDENCE BASED LEARNING: A STUDY OF IMPACT ON EXPERIENTIAL LEARNING ACTIVITIES ON ATTAINMENT OF SPECIFIC LEARNING OUTCOMES. International Journal of Research -GRANTHAALAYAH, 9(2), 2231. Retrieved from https://dx.doi.org/10.29121/granthaalayah.v9.i2.2021.3225 10 .29121/granthaalayah.v9.i2.2021.3225

Thote, P., \& S, G. (2021e). OUTCOME BASED LEARNING: A PANACEA FOR QUALITY EDUCATION. International Journal of Research -GRANTHAALAYAH, 9(5), 823. Retrieved from https://dx.doi.org/10.29121/granthaalayah.v9.i5.2021.3909 10 .29121/granthaalayah.v9.i5.2021.3909

Thote, P., \& S, G. (2021f). OUTCOME BASED LEARNING: THE EFFECT OF EXPERIENTIAL LEARNING ACTIVITIES ON THE ATTAINMENT OF SPECIFIC LEARNING OUTCOME AMONG SENIOR SECONDARY SCHOOL STUDENTS. International Journal of Research -GRANTHAALAYAH, 9(4), 28-42. Retrieved from https://dx.doi.org/10 .29121/granthaalayah.v9.i4.2021.3824 10.29121/granthaalayah.v9.i4.2021.3824 